\title{
A PCR-Based Method for the Detection of Ophiosphaerella agrostis in Creeping Bentgrass
}

John E. Kaminski and Peter H. Dernoeden, Department of Natural Resource Sciences and Landscape Architecture, University of Maryland, College Park 20742; Nichole R. O'Neill, United States Department of AgricultureAgricultural Research Service, Beltsville, MD 20705; and Henry C. Wetzel III, Syngenta Crop Protection, Inc., Vero Beach, FL, 32967

\begin{abstract}
Kaminski, J. E., Dernoeden, P. H., O’Neill, N. R., and Wetzel, H. C., III. 2005. A PCR-based method for the detection of Ophiosphaerella agrostis in creeping bentgrass. Plant Dis. 89:980985 .

Dead spot is a relatively new disease of creeping bentgrass and hybrid bermudagrass that is incited by Ophiosphaerella agrostis. Initial symptoms are difficult to diagnose and clinicians generally rely on the presence of pseudothecia within infected tissue or isolation of $O$. agrostis on an artificial medium. The main goal of this study was to develop a polymerase chain reactionbased technique capable of quickly identifying $O$. agrostis within infected creeping bentgrass tissues. Oligonucleotide primers specific for $O$. agrostis were developed based on the internal transcribed spacer (ITS) rDNA regions (ITS1 and ITS2) of three previously sequenced isolates of $O$. agrostis. The 22-bp primers amplified a 445- or 446-bp region of 80 O. agrostis isolates collected from creeping bentgrass and bermudagrass in 11 states. Primers did not amplify DNA from other common turfgrass pathogens, including three closely related species of Ophiosphaerella. Selective amplification of $O$. agrostis was successful from field-infected creeping bentgrass samples and primers did not amplify the DNA of noninfected, field-grown creeping bentgrass or hybrid bermudagrass plants. Amplification of purified O. agrostis DNA was successful at quantities between $50 \mathrm{ng}$ and $5 \mathrm{pg}$. The entire process, including DNA isolation, amplification, and amplicon visualization, may be completed within $4 \mathrm{~h}$. These results indicate the specificity of these primers for assisting in the accurate and timely identification of $O$. agrostis and the diagnosis of dead spot in both bentgrass and bermudagrass hosts.
\end{abstract}

Additional keywords: O. herpotricha, O. korrae, O. narmari

Dead spot is a disease of creeping bentgrass (Agrostis stolonifera L.) that is caused by Ophiosphaerella agrostis Dernoeden, M. P. S. Câmara, N. R. O'Neill, van Berkum et M. E. Palm $(1,4)$. The pathogen first was isolated from a golf course in Maryland in 1998 and since has been isolated from creeping bentgrass in at least 11 states (9). The pathogen also has been isolated from hybrid bermudagrass (Cynodon dactylon (L.) Pers. $\times$ C. transvaalensis Burtt-Davy) in Texas and Florida $(9,11)$.

On creeping bentgrass putting greens grown in the mid-Atlantic region of the United States, dead spot symptoms may appear as early as May and disease sever-

Corresponding author: J. E. Kaminski

E-mail: john.kaminski@uconn.edu

Current address of J. E. Kaminski: Assistant Professor, Department of Plant Science, University of Connecticut, Storrs 06269.

Financial support for this study was provided by the United States Golf Association.

Accepted for publication 4 May 2005.

DOI: 10.1094/PD-89-0980

(C) 2005 The American Phytopathological Society ity often peaks between July and August (8). Initially, the disease appears as small, copper or reddish-brown spots approximately 1 to $2 \mathrm{~cm}$ in diameter, which slowly increase to approximately 8 to $10 \mathrm{~cm}$ throughout the summer months $(4,8)$. Initial symptoms are difficult to diagnose and often are mistaken for damage caused by other common turfgrass diseases and pests such as dollar spot (Sclerotinia homoeocarpa F. T. Bennett), copper spot (Gloeocercospora sorghi Bain \& Edgerton ex Deighton), Microdochium patch (Microdochium nivale (Fr.) Samuels \& I. C. Hallett), and black cutworms (Agrotis ipsilon Hufnagel). New disease symptoms also may be confused with mechanical damage from ball marks, which typically are found on bentgrass putting greens. Once infection occurs, turfgrass in the center of dead spots dies, forming pits or depressions which adversely affect the playability of the putting surface. Recovery of bentgrass into infected spots is slow and dead spots often remain present throughout the winter until bentgrass growth resumes in the spring. Due to this slow recovery and the limited ability to manage the disease curatively, early identification of dead spot is critical.

A key diagnostic aide used to identify $O$. agrostis is the presence of pseudothecia, which often are found embedded in necrotic leaf tissue and stolons (10). These sexual fruiting bodies may develop quickly, and viable ascospores may be present within 1 week of initial symptom development (8). However, pseudothecia are not always present and isolation of $O$. agrostis on an artificial medium often is necessary for a positive laboratory diagnosis. Isolation of the pathogen, however, may take several days to weeks, and variation in colony color and morphology among $O$. agrostis isolates can make identification of the fungus difficult $(8,10)$.

Polymerase chain reaction (PCR) is a molecular technique routinely used in the identification of various fungal pathogens $(3,5,6)$. Positive identification of diseased plants may be accomplished quickly through the use of species-specific oligonucleotide primers $(3,5)$. PCR primers capable of detecting common turfgrass pathogens present at low concentrations have been developed from various regions of fungal genomic DNA. Harmon et al. (7) designed primers from the Pot 2 transposon of Magnaporthe grisea (Herbert) Barr and $M$. oryzae Couch. Another region of genomic DNA used in the development of species-specific primers is the avenacinase gene from Gaeumannomyces graminis (Sacc.) Arx \& Olivier var. avenae (E. M. Turner) Dennis (13). Conserved sequences within the internal transcribed spacer (ITS) region also have been developed to identify Rhizoctonia solani Kühn AG-2-2 as well as several subsets within this anastomosis group (2). Additionally, ITS regions (ITS1 and ITS2) previously were used in the development of primers for three other Ophiosphaerella spp. found in association with diseases of turfgrass, including $O$. herpotricha J. C. Walker, O. korrae Walker and Smith, and O. narmari Wetzel, Hulbert, and Tisserat $(12,15,16)$.

To date, based on information collected from golf courses throughout the United States, dead spot generally develops on newly constructed creeping bentgrass putting greens or renovated greens that had been fumigated with methyl bromide (9). Additionally, dead spot found on hybrid bermudagrass occurs on greens that have been overseeded with roughstalk bluegrass (Poa trivialis L.), a cool-season turfgrass species often seeded into dormant hybrid bermudagrass putting greens in the south- 
ern regions of the United States $(9,11)$. The sudden appearance of this previously undescribed pathogen on newly seeded putting greens in various regions of the United States raises the question of the pathogens' origin. The role of seed in the spread of $O$. agrostis is unknown. The development of species-specific oligonucleotide primers, however, may be useful in identifying $O$. agrostis in seed.

The main goal of this study was to develop a PCR-based technique capable of identifying $O$. agrostis within infected creeping bentgrass tissues. Therefore, the objectives of this research were to (i) develop and test oligonucleotide primers specific to $O$. agrostis and (ii) use speciesspecific primers to test for the presence of the pathogen in plants and in commercially available creeping bentgrass and roughstalk bluegrass seed.

\section{MATERIALS AND METHODS}

Fungal isolates. In all, 800 . agrostis isolates from creeping bentgrass and hybrid bermudagrass were collected from putting greens in 11 states between 1998 and 2003 (Tables 1 and 2). Other common turfgrass pathogens also were collected, including Bipolaris cynodontis (Marig.) Shoemaker; Colletotrichum graminicola (Ces.) G. W. Wils.; Gaeumannomyces graminis var. avenae; Gloeocercospora sorghi; M. poae Landschoot and Jackson; $O$. korrae; O. narmari; O. herpotricha; $R$. solani; $R$. zeae Voorhees; $R$. cerealis Van der Hoeven; and S. homoeocarpa (Table 3). Prior to DNA extraction, isolates were stored on potato dextrose agar (PDA) slants or in sterile distilled, deionized water $\left(\mathrm{ddH}_{2} \mathrm{O}\right)$ at $4^{\circ} \mathrm{C}$.

DNA isolation. To isolate the DNA from fungal cultures, isolates were grown at room temperature for 7 to 10 days in 100 $\mathrm{ml}$ of potato dextrose broth (PDB) $(24 \mathrm{~g}$ liter $^{-1}$ ) on a shaker table (LabLine Orbit Shaker, Lab-Line Instruments Inc., Melrose, IL) set to $90 \mathrm{rpm}$. Cultures were filtered through Whatman no. 1 filter paper, rinsed in $\mathrm{ddH}_{2} \mathrm{O}$, and lyophilized in a Freezemobile 6 (The VirTis Company, Gardiner, NY) for 24 to $48 \mathrm{~h}$. Freeze-dried mycelial mats were stored at $-20^{\circ} \mathrm{C}$ or immediately prepared for DNA extraction. Approximately 20 to $30 \mathrm{mg}$ of freeze-dried mycelia were placed in a $1.8-\mathrm{ml}$ microcentrifuge tube (VWR, West Chester, PA) and

Table 1. Isolate designation, cultivar affected, collection location, and date of isolation of Ophiosphaerella agrostis isolates collected from Maryland

\begin{tabular}{|c|c|c|c|}
\hline Isolate designation & Bentgrass cultivar $^{\mathrm{a}}$ & City & Isolation date \\
\hline $\mathrm{HCC} 1$ and $\mathrm{HCC} 2$ & L-93 + Crenshaw & Hunt Valley & 21 October 1998 \\
\hline OpMD-3 and OpMD-19 & Penncross & Ocean City & 16 October 1998 \\
\hline OpMD-4 and OpMD-10 & L-93 + Crenshaw & Upper Marlboro & 26 October 1998 \\
\hline OpMD-5 & L-93 + Crenshaw & Aberdeen & 15 October 1998 \\
\hline PBD1 and PBD2 & Penn G-2 & Urbana & 21 August 1998 \\
\hline OpMD-9 & Providence & Silver Spring & 13 November 1998 \\
\hline OpMD-12 & L-93 & Havre de Grace & 14 August 1999 \\
\hline OpMD-13 & 'Bardot' colonial & College Park & 8 September 1999 \\
\hline OpMD-14 and OpMD-15 & L-93 & Joppa & 26 July 2001 \\
\hline OpMD-16 & Penn A-4 & Laytonsville & 30 August 2001 \\
\hline OpMD-17 & Providence & College Park & 26 October 2001 \\
\hline OpMD-18 & Providence & College Park & 9 November 2001 \\
\hline OpMD-21 through OpMD-23 & L-93 & College Park & 20 June 2002 \\
\hline OpMD-25 through OpMD-27 & L-93 & College Park & 28 October 2002 \\
\hline OpMD-29, OpMD-34, and OpMD-40 & L-93 & College Park & 25 November 2002 \\
\hline OpMD-34 & L-93 & College Park & 25 November 2002 \\
\hline OpMD-36 & 'Bavaria' velvet & College Park & 25 November 2002 \\
\hline OpMD-40 & L-93 & College Park & 25 November 2002 \\
\hline OpMD-42 & L-93 & College Park & 28 January 2003 \\
\hline OpMD-43 through OpMD-47 & L-93 & College Park & 26 March 2003 \\
\hline OpMD-48 through OpMD-67 & L-93 & College Park & 1 October 2003 \\
\hline
\end{tabular}

${ }^{a}$ All bentgrass cultivars listed are creeping bentgrass (Agrostis stolonifera L.) unless otherwise specified.

Table 2. Isolate designation, cultivar affected, and collection location and date of various Ophiosphaerella agrostis isolates from the United States

\begin{tabular}{|c|c|c|c|}
\hline Isolate designation $^{\mathbf{a}}$ & Cultivar $^{b}$ & City, state & Date received \\
\hline OpIL-1 ${ }^{\text {RK }}$ & SR 1119 & Glencoe, Illinois & 18 December 1998 \\
\hline OpIL-2 ${ }^{\mathrm{RK}}$ & SR1119 + L-93 + Providence & Golf, Illinois & 8 December 2000 \\
\hline OpIL-3 $3^{\mathrm{RK}}$ & L-93 & Olympia Fields, Illinois & 8 December 2000 \\
\hline OpIL-4 and OpIL-5 $5^{\mathrm{RK}}$ & L-93 & Park Ridge, Illinois & 1 August 2002 \\
\hline OpMA-1 & L-93 & West Bridgewater, Massachusetts & 27 July 2002 \\
\hline OpMA-3 and OpMA-4 & Penn A-4 & Hingham, Massachusetts & Summer 2003 \\
\hline OpMI-1 and OpMI-2 & Providence & East Tawas, Michigan & 29 September 2000 \\
\hline $\mathrm{OpNC}-1^{\mathrm{HW}}$ & Penncross & Laurinburg, North Carolina & 11 August 2000 \\
\hline $\mathrm{OACS}^{\mathrm{BC}}$ & L-93 & Englishtown, New Jersey & Summer 2001 \\
\hline OpNJ-4 & L-93 & New Brunswick, New Jersey & 27 July 1999 \\
\hline OpNJ-5, OpNJ-6, and OpNJ-6b & Penn A-4 & Northfield, New Jersey & 28 September 2000 \\
\hline OpNY-1 & L-93 & Altamont, New York & 11 August 2000 \\
\hline OpOH-1 & L-93 & Chardon, Ohio & 21 October 1998 \\
\hline OpPA-1 & Crenshaw + Southshore & Avondale, Pennsylvania & 23 December 1998 \\
\hline OpPA-4 & L-93 & Honeybrook, Pennsylvania & 2 November 1999 \\
\hline OpPA-6 and OpPA-7 & SR1120 + L-93 + Providence & Avondale, Pennsylvania & 8 March 2000 \\
\hline OpPA-8 & L-93 & Honeybrook, Pennsylvania & 15 August 2000 \\
\hline OpVA-1 & Pennlinks & Sterling, Virginia & 10 September 1998 \\
\hline OpVA-3 and OpVA-4 & Penn A-4 & Virginia Beach, Virginia & 15 June 2002 \\
\hline$\# 121^{\mathrm{NT}}$ & 'Champion' bermudagrass & College Station, Texas & Summer 1999 \\
\hline
\end{tabular}

${ }^{\mathrm{a}}$ Isolates were collected in this study by author unless otherwise noted as follows; NT = Ned Tisserat, HW = Henry Wetzel, BC = Bruce Clarke, and RK = Randy Kane.

${ }^{\text {b }}$ All cultivars are creeping bentgrass (Agrostis stolonifera L.) or 'Champion' hybrid bermudagrass (Cynodon dactylon (L.) Pers. $\times$ C. transvaalensis BurttDavy). 
ground into a fine powder using a micropestle (VWR). Liquid nitrogen occasionally was used to aid in the grinding process. The DNA was extracted using DNEasy Plant Mini Kits (Qiagen Inc., Valencia, CA). For the final step, $50 \mu \mathrm{l}$ of the preheated $\left(65^{\circ} \mathrm{C}\right)$ elution buffer were added, the column centrifuged for $1 \mathrm{~min}$ at $8,000 \mathrm{rpm}$, and the step repeated. Extracted DNA then was visualized on an agarose gel and template DNA later was diluted for PCR analysis.

Development of species-specific oligonucleotide primers. Oligonucleotide primers specific for $O$. agrostis were developed based on the ITS1 and ITS2 regions of isolates OpOH-1, OpMD-6, and OpVA-1, which previously had been sequenced and deposited in the GenBank database under the accession numbers AF191550, AF191549, and AF191548, respectively (1). The primers were OaITS1 (5'-AGCAATACAGCCCAAAGGCCTC-3') and OaITS2 (5'-AAAGGCTTAATGGACGCGAGTG-3'). These primers were chosen based on nucleotide differences when ITS1 and ITS2 sequence alignments were compared among $O$. agrostis, O. herpotricha, $O$. korrae, and $O$. narmari and were designed to amplify a portion of the ITS1 region, the entire 5.8s rDNA, and a portion of the ITS2 region of all $O$. agrostis isolates (Fig. 1). Primers were synthesized by Qiagen Inc.
Genomic DNA was diluted ( $1 \mu \mathrm{l}$ of template DNA:99 $\mu \mathrm{l} \mathrm{ddH}_{2} 0$ ) for PCR reactions. The PCR reactions were run using 1 $\mu \mathrm{l}$ of $10 \times$ polymerase buffer (New England BioLabs, Inc. [NEB]; Beverly, MA), $0.4 \mu \mathrm{l}$ of $100 \mathrm{mM} \mathrm{MgSO}_{4}$ (NEB), $0.2 \mu \mathrm{l}$ of 40 $\mu \mathrm{M}$ dNTPs (NEB), $0.4 \mu \mathrm{l}$ of each $5 \mu \mathrm{M}$ primer, 0.1 unit of Taq polymerase (NEB), and $1 \mu \mathrm{l}$ of diluted genomic DNA. DNAgrade $\mathrm{ddH}_{2} \mathrm{O}$ was added to reach a reaction volume of $10 \mu \mathrm{l}$. DNA was amplified using an initial denaturation step at $94^{\circ} \mathrm{C}$ for 5 min, followed by 30 cycles of $30 \mathrm{~s}$ of denaturation at $94^{\circ} \mathrm{C}, 45 \mathrm{~s}$ of annealing at $65^{\circ} \mathrm{C}$, and $90 \mathrm{~s}$ of elongation at $76^{\circ} \mathrm{C}$. Reactions were run in an Eppendorf Mastercylcer (Hamburg, Germany), and amplification products were visualized on a 1 or $2 \%$ agarose gel stained with ethidium bromide $\left(0.5\right.$ to $\left.1.0 \mu \mathrm{g} \mathrm{ml} \mathrm{m}^{-1}\right)$. Gels were run at $125 \mathrm{~V}$ for 30 to $45 \mathrm{~min}$ in a $1 \times$ Trisacetate-EDTA (TAE) Buffer (Invitrogen, Carlsbad, CA ) containing $40 \mathrm{mM}$ Trisacetate (pH 8.3) and $1 \mathrm{mM}$ EDTA. Results were confirmed in a replication run using a different thermal cycler (PTC-0220 DNA Engine Dyad Peltier Thermal Cycler; MJ Research, Inc., Waltham, MA) with the reaction mixture and cycling profile previously described. To rule out a possible inhibition of the PCR reaction or lack of template DNA, primers specifically designed to amplify the ITS regions of $O$. korrae (15), O. narmari (16), O. herpotri-

Table 3. Isolate designation, genus and species, and host species of common turfgrass pathogens used to test the specificity of primers OaITS1 and OaITS2a

\begin{tabular}{lll}
\hline Isolate designation $^{\mathbf{b}}$ & \multicolumn{1}{c}{ Genus, species } & \multicolumn{1}{c}{ Host species } \\
\hline$\# 162^{\mathrm{NT}}$ & Ophiosphaerella korrae & Cynodon dactylon \\
$\mathrm{Lk}-5^{\mathrm{PD}}$ & O. korrae & C. dactylon \\
$\# 65^{\mathrm{NT}}$ & O. herpotricha & C. dactylon \\
$\# 189^{\mathrm{NT}}$ & O. herpotricha & C. dactylon \\
$\# 217^{\mathrm{NT}}$ & O. herpotricha & C. dactylon \\
$\# 370^{\mathrm{KM}}$ & O. narmari & C. dactylon \\
BpMD-1 & Bipolaris cynodontis & C. dactylon \\
CgMD-5 & Colletotrichum graminicola & Poa pratensis \\
GgaFR-1 & Gaeumannomyces graminis var. avenae & Agrostis stolonifera \\
GgaMD-9 & G. graminis var. avenae & A. stolonifera \\
GgaPA-1 & G. graminis var. avenae & A. stolonifera \\
GsMD-1 & Gloeocercospora sorghi & A. stolonifera \\
MpMD-3 & Magnaporthe poae & P. annua \\
RcCT-1 & Rhizoctonia cerealis & P. annua \\
RsMD-4 & R. solani & P. pratensis \\
RzMD-3 & R. zeae & Lolium perenne \\
ShVA-1 & Sclerotinia homoeocarpa & A. stolonifera \\
\hline
\end{tabular}

a ITS = internal transcribed spacer.

${ }^{\mathrm{b}}$ Isolates were collected in this study by author unless otherwise noted as follows; NT = Ned Tisserat, $\mathrm{PD}=$ Peter Dernoeden, and KM = Kevin McCann.

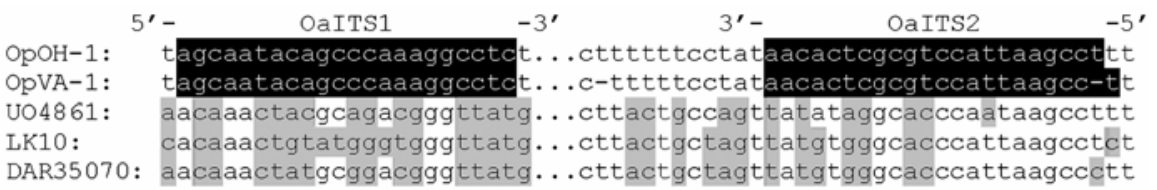

Fig. 1. Location of primers OaITS1 and OaITS2 (black background with white text) within the internal transcribed spacer (ITS) region of Ophiosphaerella agrostis isolates OpOH-1 and OpVA-1. Sequence differences among the $O$. agrostis isolates and $O$. korrae (LK10), O. herpotricha (OU4861), and $O$. narmari (DAR 03570) are shaded in gray; - indicates a single base pair difference between the two $O$. agrostis sequences and ... indicates partial sequences of the ITS1, 5.8S, and ITS2 regions not shown. cha (15), and $R$. solani (2) also were used to amplify fungal DNA of the respective turfgrass pathogens.

DNA quantification and primer sensitivity. The DNA concentrations of $O$. agrostis isolates $(n=80)$ were determined using the PicoGreen dsDNA Quantification Kit (Molecular Probes Inc., Eugene, OR; 14). Genomic DNA from each isolate was diluted (1:100) in Tris-EDTA (TE) buffer (10 mM Tris-HCl, $1 \mathrm{mM}$ EDTA, $\mathrm{pH}$ 7.5), and $50 \mu \mathrm{l}$ of diluted DNA were added to 50 $\mu \mathrm{l}$ of the PicoGreen reagent (diluted to $1 \times$ concentration with TE buffer). Hence, the final DNA dilution for detection was 1:200 (vol/vol). Six calibration samples containing DNA stock solutions of previously determined concentrations were used to develop a standard curve. The DNA quantification was performed using a Fluoroskan Ascent Microplate Fluorometer (Thermo Labsystems, Franklin, MA). Prior to quantification, samples were shaken for $10 \mathrm{~s}$ and incubated for $5 \mathrm{~min}$ at $28^{\circ} \mathrm{C}$. Immediately following incubation, DNA concentrations were quantified at an excitation $(485 \mathrm{~nm})$ and emission $(538 \mathrm{~nm})$ wavelength specific for the fluorescent dye.

To assess the sensitivity of the developed primers for detecting O. agrostis, stock DNA was diluted and PCR performed on known DNA concentrations. Primers developed in this study were tested against DNA quantities of 50, 5.0, and $0.5 \mathrm{ng}$ and 50 and $5 \mathrm{pg}$. Previously isolated DNA from five $O$. agrostis isolates were selected for the sensitivity assay and the experiment was repeated twice.

Detection of $\boldsymbol{O}$. agrostis in creeping bentgrass. Field samples of creeping bentgrass exhibiting symptoms of dead spot were collected from a research putting green at the Paint Branch Turfgrass Research Facility (PBTRF) located in College Park, MD. Additionally, primers were tested on $O$. agrostis-infected creeping bentgrass from Black Rock Country Club (BRCC) located in Massachusetts. The presence of $O$. agrostis was confirmed either by isolation or the presence of pseudothecia and ascospores characteristic of the species. Samples of putatively noninfected plant tissues adjacent to dead spot infection centers were used as a negative control. In addition, healthy hybrid bermudagrass plants were collected from a National Turfgrass Evaluation Program (NTEP, Beltsville, MD) variety trial located at PBTRF and used as a negative control for the primers. Isolation of DNA from all plant material was performed using the aforementioned DNEasy extraction kit and procedures described above. The DNA from a single $O$. agrostis isolate (OpVA-4) served as a positive control and was included in all PCR reactions involving diseased plants and seeds.

Identification of $\boldsymbol{O}$. agrostis in creeping bentgrass seed. Primers were used in 
an attempt to amplify $O$. agrostis DNA from commercial creeping bentgrass seed. In addition to creeping bentgrass, primers were evaluated against the DNA from seed of four roughstalk bluegrass cultivars, including 'Snowbird', 'Sabre', 'Winterplay', and 'Bariviera'. All roughstalk bluegrass seed was provided by Kevin Morris of the NTEP. Seed DNA were extracted using the DNEasy Plant Mini Kit, with the same procedural specifications previously described with the following modifications. A total of 200 to $300 \mathrm{mg}$ of seed was ground in autoclaved mortars and pestles with liquid nitrogen at the start of the extraction procedure. The DNA extraction generally was replicated twice for each seed sample and amplification with primers OaITS1 and OaITS2 was attempted twice for each DNA sample. Only seed collected from Philadelphia Country Club (PCC) and BRCC were known to have been used to establish putting greens that were later diagnosed with dead spot. A total of 10 DNA isolations were made from seed collected from PCC and BRCC, and PCR again tested twice per sample. Extracted DNA was confirmed by running a sample aliquot on an agarose gel and visualizing the DNA fragment under UV light. Amplification procedures were identical to those described previously.

\section{RESULTS AND DISCUSSION}

Fungal isolation. In all, $80 \mathrm{O}$. agrostis isolates were tested in this study (Tables 1 and 2). Colony morphology varied when grown on PDA and incubated in the dark at $25^{\circ} \mathrm{C}$ for 10 days. Most isolates collected exhibited a typical rose-quartz or pink colony color previously described $(1,4,10)$. Several other isolates appeared olive-gray or buff and were similar in colony color to the original description of the Ohio isolate $(\mathrm{OpOH}-1)(1,10)$. Isolates OpNC-1 and OpNJ-6 fit into a previously undescribed mycelial color class, and were gray when grown on PDA under the aforementioned conditions. A complete description of most of the isolates tested was reported previously (8).

Development of species-specific oligonucleotide primers. The selected primers amplified a putative 445- or 446-bp amplicon in each of the $80 \mathrm{O}$. agrostis isolates tested in this study (Figs. 2 and 3). The 446-bp amplicon resulted from amplification of the OpOH-1 isolate, which had an additional 2 nucleotides in the ITS sequences reported by Câmara et al. (1). It is unknown if other isolates with morphology similar to the aforementioned Ohio isolate contained an additional base pair. The OaITS2 primer developed in this study resided between the two nucleotide differences and, therefore, amplification of the isolates was not impacted. Primers did not amplify DNA from 11 other turfgrass pathogens tested, including three different Ophiosphaerella spp. (Fig. 4). The speci-
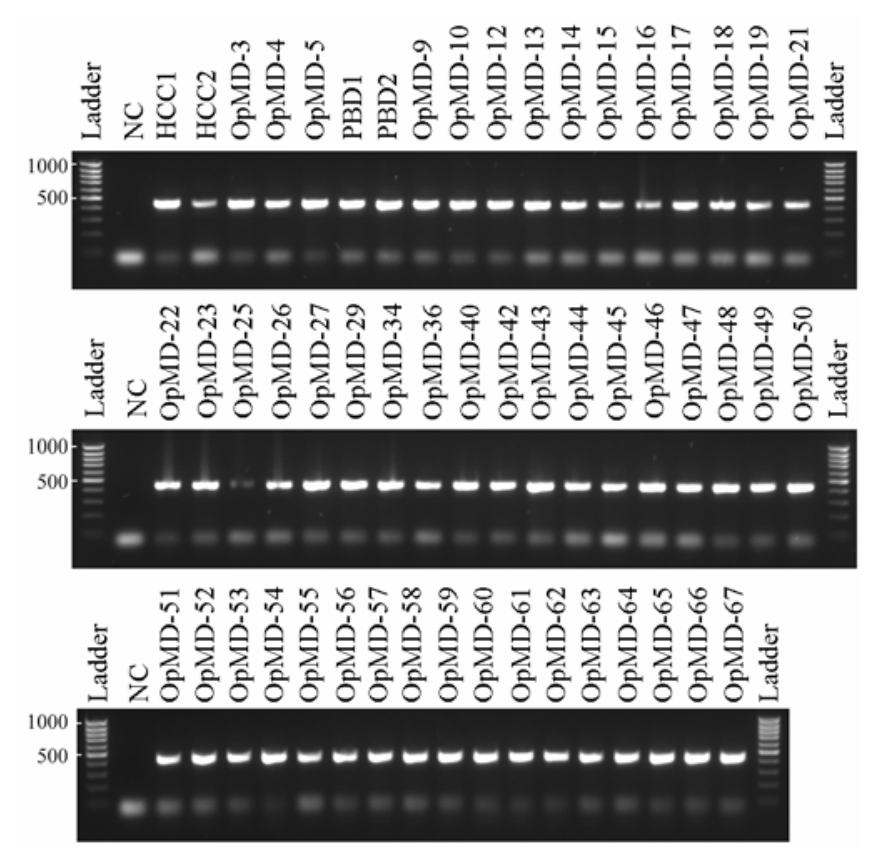

Fig. 2. Polymerase chain reaction product amplified from the internal transcribed spacer region of DNA from $(n=53)$ Ophiosphaerella agrostis isolates collected in Maryland. A negative control (NC) and 100-bp ladder are shown.

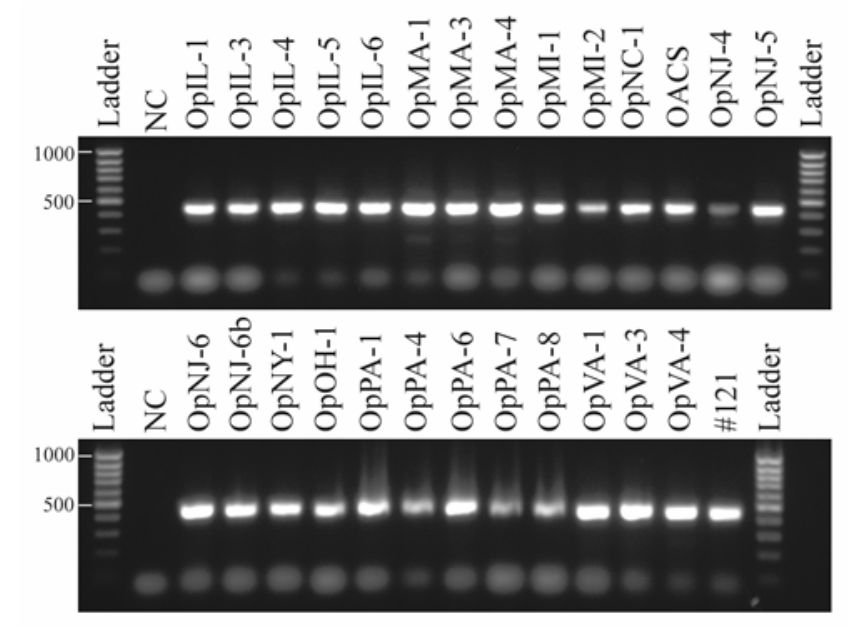

Fig. 3. Polymerase chain reaction product amplified from the internal transcribed spacer region of DNA from $(n=27)$ Ophiosphaerella agrostis isolates from 10 states. A negative control (NC) and 100bp ladder are shown.

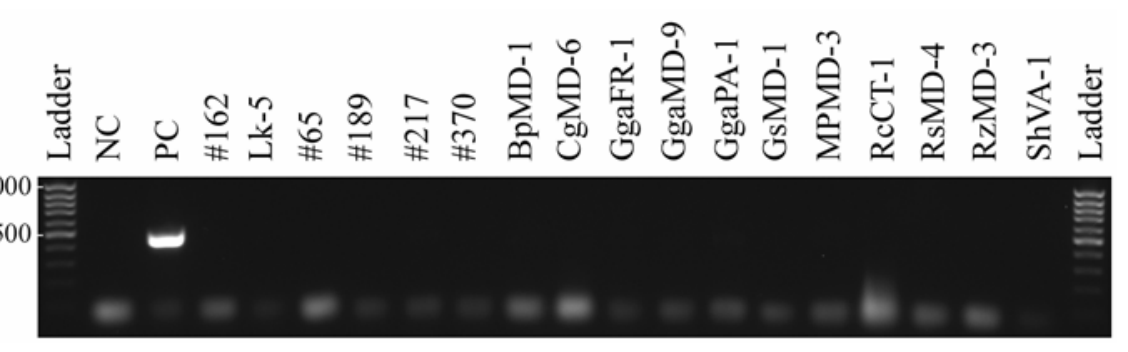

Fig. 4. Polymerase chain reaction amplification of fungal DNA from various turfgrass pathogens. From left to right: 100-bp ladder, negative control (NC), positive control (PC; OpVA-4), Ophiosphaerella korrae (\#162, Lk-5), O. herpotricha (\#65, \#189, \#217), O. narmari (\#370), Bipolaris cynodontis (BpMD-1), Colletotrichum graminicola (CgMD-6), Gaeumannomyces graminis var. avenae (GgaFR1, GgaMD-9, GgaPA-1), Gloeocercospora sorghi (GsMD-1), Magnaporthe poae (MpMD-3), Rhizoctonia cerealis (RcCT-1), R. solani (RsMD-4), R. zeae (RzMD-3), Sclerotinia homoeocarpa (ShVA-1), and a 100-bp ladder. 
ficity of the $O$. agrostis primers was based on the unique sequences of the ITS 1 and ITS2 regions chosen when compared with $O$. herpotricha, $O$. korrae, and $O$. narmari. The annealing temperature of $65^{\circ} \mathrm{C}$ was chosen to closely match the melting temperature of the primers and to eliminate the potential of priming a reaction with the three closely related Ophiosphaerella spp. There were no differences in the selective amplification of $O$. agrostis DNA when reactions were run in either thermal cycler. Selective amplification of $O$. agrostis was successful from each of the field-infected creeping bentgrass samples ( $n=8$; Fig. 5$)$. Primers did not amplify the DNA of uninfected, field-grown creeping bentgrass $(n=$ $4)$ or hybrid bermudagrass $(n=4)$ plants. These results indicate the specificity of this assay for assisting in the identification of $O$. agrostis and the diagnosis of dead spot in both bentgrass and bermudagrass species.

DNA quantification and primer sensitivity. Quantification of the six calibration samples resulted in the linear equation $y=$ $0.090 x-0.017\left(R^{2}=0.99\right)$, where $y=$ strength of the PicoGreen emission wavelength $(\mathrm{nm})$ and $x=$ DNA concentration $\left(\mu \mathrm{g} \mathrm{ml}^{-1}\right)$. The DNA concentrations of 13 isolates were considered to be outside the desired range for detection; therefore, concentrations for these samples were extrapolated from the regression equation. Total DNA extracted from $O$. agrostis isolates (20 to $30 \mathrm{mg}$ of freeze-dried mycelium) using the DNeasy DNA isolation kit averaged $18.03 \mathrm{ng}^{-1} \mathrm{l}^{-1}$ (range $=0.73$ to $224.26 \mathrm{ng}^{-1} \mathrm{l}^{-1}$, data not shown).

Early attempts to amplify portions of $O$. agrostis DNA were erratic when total extracted stock DNA was used in the amplification procedure. Therefore, total purified $O$. agrostis DNA $(n=5)$ was diluted to varying levels to determine the sensitivity to the developed primers. Amplification of purified $O$. agrostis DNA was successful at quantities ranging between $50 \mathrm{ng}$ and $5 \mathrm{pg}$ (data not shown). Amplification of the five isolates generally was detected with all quantities of DNA. Although attempts to amplify the pathogen generally were successful, DNA amplification of isolates OpMD-16 and OpMD-25 resulted in vary- ing inconsistencies. The characteristic amplicon, however, always was present for the aforementioned isolates when $5 \mathrm{ng}$ of DNA was used in the assay. Amplification of the other isolates generally resulted in the presence of the distinctive amplicon at all concentrations analyzed in this study. This PCR-based technique is very sensitive and results were similar to that reported by Harmon et al. (7) for Magnaporthe spp. Amplification of $O$. agrostis was possible with amounts of DNA as low as 5 pg. Regardless of extracted DNA concentration, amplification of $O$. agrostis with primers OaITS1 and OaITS2 was successful when stock DNA from pure cultures or infected creeping bentgrass plants was diluted $1: 100$.

Identification of $\boldsymbol{O}$. agrostis in creeping bentgrass seed. Primers were used in an attempt to amplify DNA of $O$. agrostis from commercially available creeping bentgrass and roughstalk bluegrass seed. Due to the appearance of dead spot in the years following seeding, many golf course managers did not have seed available for testing. In all, 20 seed samples were collected from various locations, however, only seed from PCC and BRCC was known to have been planted into greens in which dead spot occurred. Amplification of $O$. agrostis DNA was successful only on a single attempt in seed from PCC (data not shown). Attempts to repeat this amplification from the template DNA of the aforementioned sample and from additional DNA extractions of all collected seed were unsuccessful. Although not examined, it is unclear whether inhibitors within the extracted seed DNA were present that may have prevented successful amplification during the PCR reaction. Attempts to culture the fungus directly from seed plated on water agar yielded several unknown fungal species, but $O$. agrostis was not isolated.

Although the pathogen was not consistently detected in seed tested in this study, the role of seed in the spread of $O$. agrostis remains unclear. In this study, very small quantities of seed were tested for the presence of $O$. agrostis. Seeded at a standard rate of $50 \mathrm{~kg} \mathrm{ha}^{-1}$, a total of $2.8 \mathrm{~kg}$ of bentgrass seed would be needed to establish an

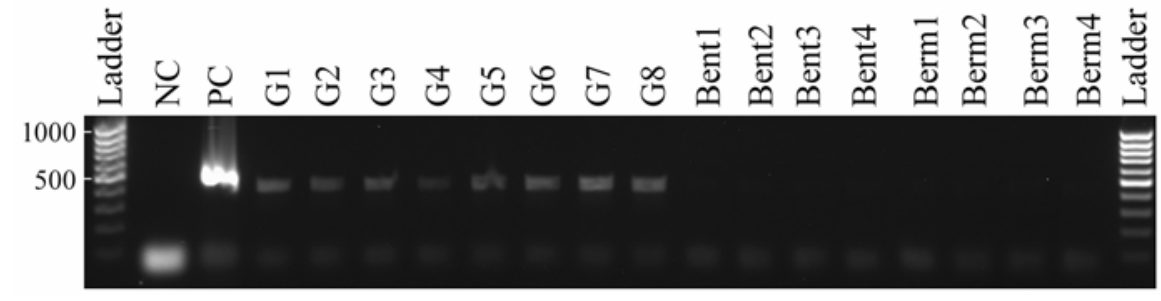

Fig. 5. Polymerase chain reaction amplification of fungal DNA from field-infected creeping bentgrass. From left to right: 100-bp ladder, negative control (NC), positive control (PC; OpVA-4), Ophiosphaerella agrostis-infected bentgrass plants (G1-G8), asymptomatic creeping bentgrass (Bent1-Bent4), and hybrid bermudagrass (Berm1-Berm4) plants, and a 100-bp ladder. average-sized putting green (e.g., $557 \mathrm{~m}^{2}$ ). Based on the quantity of seed tested in this study (400 to $600 \mathrm{mg}$ sample $\mathrm{e}^{-1}$ ), only $1.4 \times$ $10^{-4}$ to $2.2 \times 10^{-4} \%$ of the seed used to establish an average-sized putting green was evaluated for the presence of $O$. agrostis. Information on the introduction of $O$. agrostis into the United States is still limited. $O$. agrostis was identified on Schizostachyum lima (Blanco) Merr., a bamboo-like plant native to Indonesia that was quarantined by the Animal and Plant Health Inspection Services in 2000 (N. R. O'Neill, unpublished). However, the possible role of ornamental grasses in the introduction of the pathogen into United States is unknown.

Dead spot can be difficult to diagnose from field samples if pseudothecia are not present; diagnosis often requires isolation of the pathogen to obtain a positive identification. Isolation in pure culture, however, may take several days, and variation in colony color makes accurate identification of the pathogen difficult (10). Primers developed in this study were capable of detecting $O$. agrostis in pure culture and within infected creeping bentgrass in as little as $4 \mathrm{~h}$. Due to the novelty of this pathogen and the sometimes difficult diagnosis of the disease, these primers will assist diagnostic labs in the identification of dead spot. Molecular techniques, PCR in particular, continue to improve the accuracy and speed of diagnosing plant pathogens. Early diagnosis will assist turf managers in implementing management strategies that help reduce damage caused by dead spot.

\section{ACKNOWLEDGMENTS}

We thank E. C. Synkowski for technical assistance; B. Clarke, R. Kane, K. McCann, and N. Tisserat for providing isolates; and K. Morris for donating seed.

\section{LITERATURE CITED}

1. Câmara, M. P. S., O'Neill, N. R., van Berkum, P., Dernoeden, P. H., and Palm, M. E. 2000 Ophiosphaerella agrostis sp. nov. and its relationship to other species of Ophiosphaerella. Mycologia 92:317-325.

2. Carling, D. E., Kuninaga, S., and Brainard, K. A. 2002. Hyphal anastomosis reactions, rDNA-internal transcribed spacer sequences, and virulence levels among subsets of Rhizoctonia solani Anastomosis group-2 (AG-2) and AG-BI. Phytopathology 92:43-50.

3. Chiocchetti, A., Sciaudone, L., Durando, F., Garibaldi, A., and Migheli, Q. 2001. PCR detection of Fusarium oxysporum f. sp. basilici on basil. Plant Dis. 85:607-611.

4. Dernoeden, P. H., O’Neill, N. R., Câmara, M. P. S., and Feng, Y. 1999. A new disease of Agrostis palustris incited by an undescribed species of Ophiosphaerella. Plant Dis. 83:397.

5. Errampalli, D., Saunders, J., and Cullen, D. 2001. A PCR-based method for detection of potato pathogen, Helminthosporium solani, in silver scurf infected tuber tissue and soils. J. Microbiol. Methods 44:59-68.

6. Godfrey, S. A., Monds, R. D., Lash, D. T., and Marshall, J. W. 2003. Identification of Pythium oligandrum using species-specific ITS rDNA PCR oligonucleotides. Mycol. Res. 107:790796. 
7. Harmon, P. F., Dunkle, L. D., and Latin, R. 2003. A rapid PCR-based method for the detection of Magnaporthe oryzae from infected perennial ryegrass. Plant Dis. 87:1072-1076.

8. Kaminski, J. E. 2004. Biology of Ophiosphaerella agrostis, epidemiology of dead spot, and a molecular description of the pathogen. Ph.D. diss. University of Maryland, College Park.

9. Kaminski, J. E., and Dernoeden, P. H. 2002. Geographic distribution, cultivar susceptibility, and field observations on bentgrass dead spot. Plant Dis. 86:1253-1259.

10. Kaminski, J. E., Dernoeden, P. H., O’Neill, N. R., and Momen, B. 2002. Reactivation of bentgrass dead spot and growth, pseudothecia production, and ascospore germination of
Ophiosphaerella agrostis. Plant Dis. 86:12901296.

11. Krausz, J. P., White, R. H., Foerster, W., Tisserat, N. A., and Dernoeden, P. H. 2001. Bermudagrass dead spot: A new disease of bermudagrass caused by Ophiosphaerella agrostis. Plant Dis. 85:1286.

12. O'Gorman, D., Xue, B., Hsiang, T., and Goodwin, P. H. 1994. Detection of Leptosphaeria korrae with polymerase chain reaction and primers from the ribosomal internal transcribed spacers. Can. J. Bot. 72:342-346.

13. Rachdawong, S., Cramer, C. L., Grabae, L. A., Stromberg, V. K., Lacy, G. H., and Stromberg, E. L. 2002. Gaeumannomyces graminis vars. avenae, graminis, and tritici identified using PCR amplification of avenacinase-like genes.
Plant Dis. 86:652-660.

14. Singer, V. L., Jones, L. J., Yue, S. T., and Haugland, R. P. 1997. Characterization of PicoGreen reagent and development of a fluorescence-based solution assay for double-stranded DNA quantitation. Anal. Biochem. 249:228 238.

15. Tisserat, N. A., Hulbert, S. H., and Sauer, K. M. 1994. Selective amplification of rDNA internal transcribed spacer regions to detect Ophiosphaerella korrae and O. herpotricha. Phytopathology 84:478-482.

16. Wetzel, H. C., III, Hulbert, S. H., and Tisserat, N. A. 1999. Molecular evidence for the presence of Ophiosphaerella narmari n. comb., a cause of spring dead spot of Bermuda grass, in North America. Mycol. Res. 103:981-989. 